\title{
The effect of dietary fats on the composition of the liver endoplasmic reticulum and oxidative drug metabolism
}

\author{
BY CATHERINE T. HAMMER AND E. D. WILLS \\ Department of Biochemistry, The Medical College of St Bartholomew's Hospital, \\ Charterhouse Square, London ECI $M 6 B Q$
}

(Received 13 July 1978 - Accepted 3 November 1978)

I. The dependence of the rate of oxidative demethylation in the liver endoplasmic reticulum on the fatty acid composition of the endoplasmic reticulum has been studied by varying the lipid content of the diet.

2. The rate of oxidative demethylation was markedly dependent on the percentage of linoleic acid (18:2) incorporated into the membrane. Feeding diets containing $(\mathrm{g} / \mathrm{kg})$ 100 coconut oil, 100 lard or 100 maize oil caused respectively the incorporation of $7.6,10.3$ and $25.1 \%$ linoleic acid (18:2) and a demethylation rate of $3.26,3.15$ and $5.03 \mathrm{nmol}$ formaldehyde/min per $\mathrm{mg}$ protein. Feeding $100 \mathrm{~g}$ herring oil $/ \mathrm{kg} \mathrm{diet}$ caused incorporation of only $5 . \mathrm{I} \% \mathrm{C}_{18: 2}$ but also $27 \cdot 2 \% \omega_{3}$ unsaturated fatty acids, including $8.7 \%$ eicosapentaenoic acid (20:5) and $17.0 \%$ docosahexaenoic acid (22.6) and caused a very high rate of oxidative demethylation $(6.53 \mathrm{nmol}$ formaldehyde/min per $\mathrm{mg}$ protein).

3. Destruction of the polyunsaturated fatty acids in herring oil by irradiation with 400 krad caused incorporation of a smaller quantity of $\omega_{3}$ unsaturated acids into the endoplasmic reticulum and decreased the rate of oxidative demethylation $(4.83 \mathrm{nmol}$ formaldehyde $/ \mathrm{min}$ per $\mathrm{mg}$ protein).

4. The inductive effects of phenobarbitone on oxidative demethylation were partially dependent on changes in the fatty acid composition of the endoplasmic reticulum. Phenobarbitone $(100 \mathrm{mg} / \mathrm{kg})$ increased the percentage of $C_{18: 2}$ from $25 . \mathrm{I}$ to $29.4 \%$ in rats given a maize-oil diet, increased the percentage of $C_{20: 5}$ from 8.7 to $10.3 \%$ in rats given a herring-oil diet and decreased the percentage of arachidonic acid (20:4) and $\mathrm{C}_{22: 6}$ in rats given a lard, maize-oil, herring-oil or irradiated-herring-oil diet.

5. Intraperitoneal $\alpha$-tocopherol $(50 \mathrm{mg} / \mathrm{kg})$ increased the percentage of $\mathrm{C}_{20: 4}$ from II-I to I $3 . \mathrm{I} \%$ in rats given a lard diet and from 5.9 to $7.3 \%$ in rats given a herring-oil diet.

6. It is concluded that dietary $C_{18: 2}$ is an important factor in the regulation of the rate of oxidative denethylation in the liver endoplasmic reticulum but this may be replaced effectively by dietary $C_{20: 5} \omega_{3}$ and $C_{22: 6}$ $\omega_{3}$ acids. Oxidative demethylation is regulated by changes in the fatty acid composition of the membranes of the liver endoplasmic reticulum.

The endoplasmic reticulum in the liver is responsible for the oxidative metabolism of a wide variety of drugs and carcinogens and membrane integrity is essential for oxidative metabolism (Lu et al. 1969; Strobel et al. 1970).

The stability and permeability of membranes in the endoplasmic reticulum depends on the phospholipids and these are markedly influenced by the nature, extent of unsaturation and arrangement of their constituent fatty acids (Lucy, 1972; Chapman, 1973). Wills (1971) has shown that lipid peroxidation, which causes fragmentation of polyunsaturated fatty acids of membrane phospholipids, leads to a marked decrease in the rate of oxidative demethylation,

The conformation of the fatty acyl chains of membrane phospholipids in the liver may be important in holding the cytochrome $P 450$ complex in an active conformation in the endoplasmic reticulum membrane or in forming a fluid environment which facilitates electron transfer from NADPH to cytochrome $P_{450}$ (Ingelman-Sundberg \& Gustafsson, 1975; Ingelman-Sundberg, 1977).

The nature of the dietary lipid, and especially the content of polyunsaturated fatty acids regulates oxidative drug and carcinogen metabolism in the liver endoplasmic reticulum (Rowe \& Wills, 1976; Lambert \& Wills, 1977a, b) and it is thus possible that the dietary lipid alters the rate of oxidative metabolism by modification of the fatty acid composition of the endoplasmic reticulum. 
In the experiments described in this paper, the effect of the fatty acid composition of the dietary lipid on the fatty acid composition of the liver endoplasmic reticulum has been studied and related to oxidative enzyme activity.

\section{EXPERIMENTAL}

\section{Animals and diets}

Male albino Wistar rats bred in the animal colony at St Bartholomew's Hospital Medical College, 6-7 weeks old, weighing I20-150 g, were used in all experiments. Food and water were available ad lib.

Casein (fat-free) was obtained from Unigate Ltd, Wilts, wheat starch from Adcol Ltd, Slough, Bucks, dried yeast from Bovril Ltd, Burton on Trent, Staffs, and Rovimix $\mathrm{AD}_{3}$, supplying $150 \mathrm{mg}$ retinol and $2.5 \mathrm{mg}$ cholecalciferol/g from Roche Ltd, London, Wr. Antioxidant-free lard was obtained from Unigate Ltd, coconut oil from the Tropical Products Institute, London, and refined herring oil from the Marfleet Refining Co., Hull.

For the purpose of comparison, in some experiments rats were fed on Spratts Laboratory Rat Diet No. I (Spratts Ltd, Barking, Essex). Purified diets contained (g/kg): 250 casein, 200 sucrose, 300 wheat starch, I00 dried yeast, I00 lard, herring oil, coconut oil or maize oil (Mazola C.P.C.) and 50 Cox's salt mix (Diplock et al. 196I). The diet was supplemented with Rovimix $\mathrm{AD}_{3}$ supplying $1500 \mu \mathrm{g}$ retinol and $25 \mu \mathrm{g}$ cholecalciferol $/ \mathrm{kg}$ diet. Feeding commenced immediately after preparation of the diets.

\section{Experimental design}

Groups of twenty to forty rats were fed on stock diet or on purified diets containing $(\mathrm{g} / \mathrm{kg})$ : 100 lard, I00 coconut oil, Ioo maize oil or Ioo herring oil, untreated or subjected to a $400 \mathrm{krad}$ dose of $\gamma$-rays. Diets were fed immediately after preparation ( $3 \mathrm{~d}$ after irradiation). Two rats were killed $10 \mathrm{~d}$ after starting feeding and then at intervals of $2 \mathrm{~d}$ for a total period of $10-25 \mathrm{~d}$. Preparations of liver endoplasmic reticulum were made for measurements of the rate of oxidative demethylation of aminopyrine and for analysis of the fatty acid composition as described below. In some experiments, pairs of rats were killed at daily intervals after feeding commenced to establish the time interval required for stabilization of the rate of oxidative metabolism and fatty acid composition. Both the rate of metabolism and fatty acid composition usually stabilized Io d after starting on a new diet and thus, in the majority of experiments, analyses were commenced after this period.

\section{Experimental procedures}

Irradiation of herring-oil diets. Irradiations were carried out using a $1500 \mathrm{Ci}^{60} \mathrm{Co}$ gamma beam unit made by Atomic Energy of Canada Ltd, Ottawa, Canada. Mixtures of herring oil $(\mathrm{I} 00 \mathrm{~g})$ and starch $(300 \mathrm{~g})$ were irradiated with $400 \mathrm{krad}$ and, after $3 \mathrm{~d}$, added to the remainder of the untreated diet $(600 \mathrm{~g})$ to make I $\mathrm{kg}$ complete diet. Samples $(400 \mathrm{~g})$ of the herring oil-starch mixture were placed in polyethylene bags in a Perspex frame $(250 \mathrm{~mm} \times 250 \mathrm{~mm}$ $\times 40 \mathrm{~mm}$ ) at a distance of $400 \mathrm{~mm}$ from the ${ }^{60} \mathrm{Co} \gamma$-ray source and irradiated with $400 \mathrm{krad}$. The dose rate at $400 \mathrm{~mm}$ from the source was calculated from the rate of decay of ${ }^{60} \mathrm{Co}$ ( $\mathrm{I} \% /$ month) and was checked regularly using ferrous sulphate solutions (Fricke et al. 1938).

Determinations of the fatty acid composition of the diets. Lipid from diet samples was extracted in hexane containing 2,6-di-t-butyl-4-methyl phenol (BHT; $5 \mathrm{mg} / 100 \mathrm{ml}$ ) and methylated by the method of Morrison \& Smith (1964). Separation and determination of 
the fatty acid methyl esters by gas-liquid chromatography was performed as described by Davison \& Wills (1974).

Phenobarbitone administration. At $10 \mathrm{~d}$ after starting on the diets, animals received phenobarbitone either as a single intraperitoneal injection $(100 \mathrm{mg} / \mathrm{kg})$. of sodium phenobarbitone dissolved in saline ( $9 \mathrm{~g}$ sodium chloride/1) or in solution as the source of drinkingwater ( $\mathrm{I} \mathrm{mg} / \mathrm{ml}$ ).

$\alpha$-Tocopherol administration. Animals received $\alpha$-tocopherol as an intraperitoneal injection of DL- $\alpha$-tocopherol acetate $\left(50 \mathrm{mg} / \mathrm{kg}\right.$; Roche Ltd, London, $\mathrm{W}_{\mathrm{I}}$ ).

Preparation of the microsomal fraction. The microsomal fraction of the liver was prepared by a calcium precipitation method described by Kamath \& Rubin (1972). The microsomal pellet was resuspended in $125 \mathrm{~mm}$-potassium chloride $(0.5 \mathrm{~g}$ liver $/ \mathrm{ml})$ to make a $500 \mathrm{mg} / \mathrm{ml}$ microsomal suspension.

Determination of oxidative demethylation. The rate of oxidative demethylation of aminopyrine was determined as described by Rowe \& Wills (I976).

Extraction of lipids from the endoplasmic reticulum. The unsaturated fatty acids present in the endoplasmic reticulum are particularly vulnerable to peroxidation (May \& McCay, I968). For this reason the antioxidant BHT was added to the solvents used to extract the lipids $(5 \mathrm{mg} / \mathrm{I} 00 \mathrm{ml})$ and to all solvents used in handling them subsequently. Lipids were extracted from the endoplasmic reticulum with chloroform-methanol $(2: \mathrm{I}, \mathrm{v} / \mathrm{v})$ as described by Recknagel \& Ghoshal (I966). The lipids were redissolved in a small quantity of hexane and stored in Quick-Fit tubes (Quickfit \& Quartz Ltd, Staffs) under nitrogen at - $20^{\circ}$.

Determination of the fatty acid composition of the endoplasmic reticulum. Lipids of the endoplasmic reticulum were methylated as described for diet samples (Morrison \& Smith, 1964). The fatty acid methyl esters were separated and determined by gas-liquid chromatography (Davison \& Wills, 1974).

\section{RESULTS}

\section{Analysis of the diets}

The fatty acid compositions of the diets are compared in Table I. Spratts Laboratory Rat Diet No. I contained $\mathrm{I} 44 \mathrm{~g}$ linoleic acid $(18: 2) / \mathrm{kg}$ and no other polyunsaturated fatty acids. Coconut oil is a highly-saturated lipid comprising $9 \mathrm{I} 6 \mathrm{~g}$ saturated fatty acids and only $12 \mathrm{~g} \mathrm{C}_{18: 2} / \mathrm{kg}$. Lard contained $475 \mathrm{~g}$ saturated fatty acids, $453 \mathrm{~g}$ monounsaturated acids and $74 \mathrm{~g} \mathrm{C}_{18: 2} / \mathrm{kg}$. Maize oil contained $552 \mathrm{~g} \mathrm{C}_{18: 2} / \mathrm{kg}$ and a high concentration of the natural anti-oxidant $\alpha$-tocopherol ( $\mathrm{mg} / \mathrm{g}$ maize oil ; Rowe \& Wills, 1976) which protects the polyunsaturated fatty acids from peroxidation. Herring oil contained $229 \mathrm{~g}$ highly unsaturated fatty acids, including $79 \mathrm{~g}$ eicosapentaenoic acid (20:5) and $\mathrm{IOI} \mathrm{g}$ docosahexaenoic acid (22:6) $/ \mathrm{kg}$ but only $19 \mathrm{gC}_{18: 2} / \mathrm{kg}$.

Irradiation of $100 \mathrm{~g}$ herring oil $+300 \mathrm{~g}$ starch with $400 \mathrm{krad}$ caused some destruction of all polyunsaturated fatty acids which increased with the period of time after irradiation (Table 2). By $13 \mathrm{~d}$ after irradiation marked decreases in the proportions of highly unsaturated fatty acids, particularly $\mathrm{C}_{20: 5}$ and $\mathrm{C}_{22: 6}$, were evident and, $20 \mathrm{~d}$ after irradiation, all highly unsaturated fatty acids had disappeared from the diet. The proportion of $\mathrm{C}_{18: 2}$ had decreased $20 \mathrm{~d}$ after irradiation and after $27 \mathrm{~d}$ all the $\mathrm{C}_{18: 2}$ had disappeared from the diet (Table 2).

\section{The effect of the dietary lipid on oxidative demethylation}

The rate of oxidative demethylation of aminopyrine in the endoplasmic reticulum of rats fed on a coconut-oil or lard diet was lower, both before $(P<0.0 \mathrm{I})$ and after induction $(P<0.0 \mathrm{I})$ than in rats fed on a maize-oil diet for $10-25 \mathrm{~d}$ (Table 3$)$. The rate of aminopyrine demethylation in rats fed on a herring-oil diet was higher before induction $(P<0.0 \mathrm{I})$ 
Table I. Fatty acid composition $(\mathrm{g} / \mathrm{kg})$ of diets

(Mean values with their standard errors)

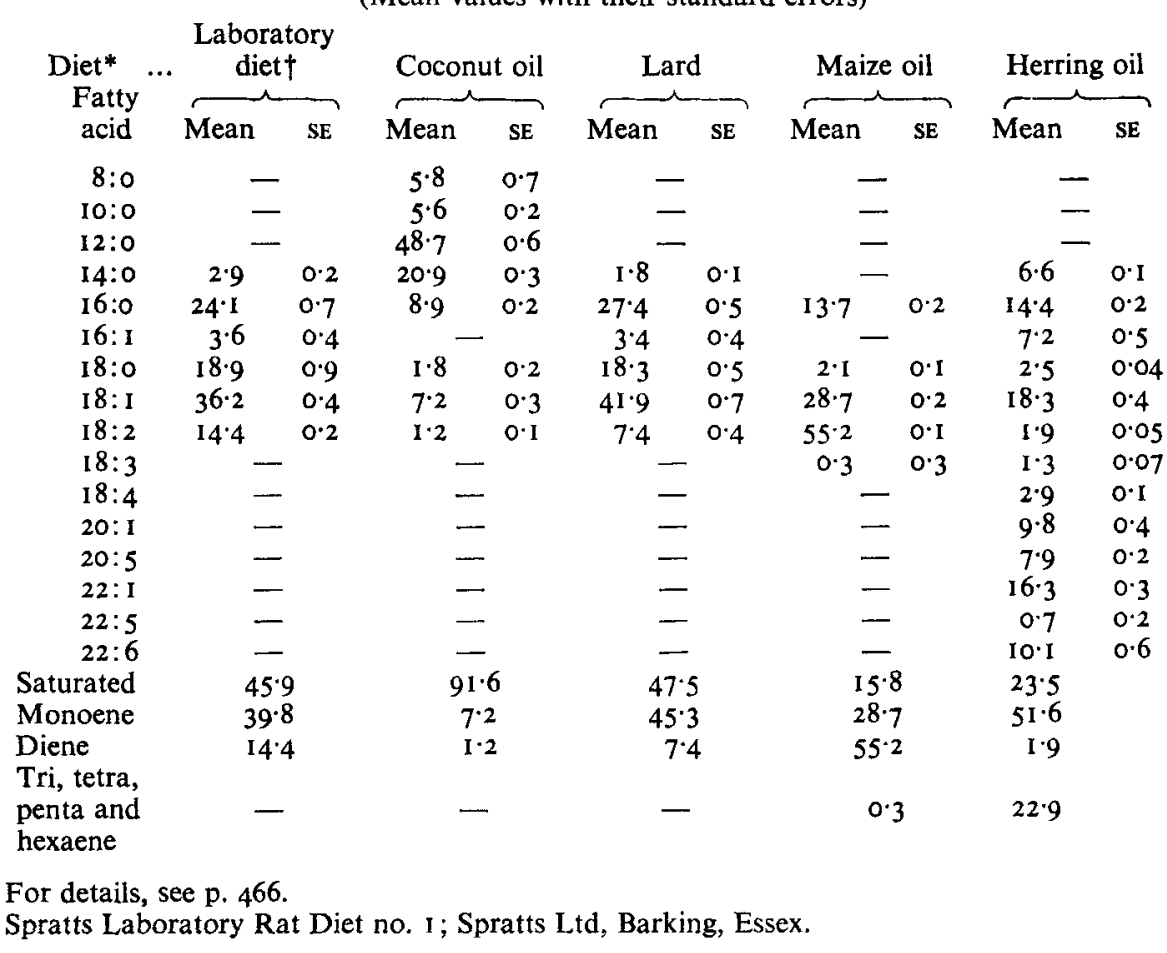

Table 2. Fatty acid composition $(\mathrm{g} / \mathrm{kg})$ of $100 \mathrm{~g}$ herring-oil/kg diet after irradiation with $400 \mathrm{krad}^{*}$

(Mean values with their standard errors for eight determinations for control samples and means of two determinations for irradiated samples)

\begin{tabular}{|c|c|c|c|c|c|c|}
\hline \multirow{2}{*}{$\begin{array}{c}\text { Fatty } \\
\text { acid }\end{array}$} & \multicolumn{2}{|c|}{ Control } & \multicolumn{4}{|c|}{ Time interval after irradiation of herring oil (d) } \\
\hline & Mean & $\mathrm{SE}$ & 6 & 13 & 20 & 27 \\
\hline $14: 0$ & 6.6 & $0 \cdot I$ & $5 \cdot 7$ & $8 \cdot 3$ & 9.0 & $9 \cdot 0$ \\
\hline $16: 0$ & 14.4 & 0.2 & 16.4 & $20 \cdot 7$ & 24.0 & $22 \cdot 1$ \\
\hline I6:1 & 7.2 & 0.5 & $7 \cdot 6$ & $9 \cdot I$ & $8 \cdot 8$ & $9 \cdot 0$ \\
\hline 18:0 & $2 \cdot 5$ & 0.04 & $2 \cdot 7$ & $2 \cdot 8$ & $2 \cdot 9$ & $3 \cdot 2$ \\
\hline I 8: I & $18 \cdot 3$ & 0.4 & $19 \cdot 3$ & 22.8 & $22 \cdot 3$ & $23 \cdot 2$ \\
\hline I 8:2 & I'9 & 0.05 & $1 \cdot 9$ & $1 \cdot 8$ & 0.5 & - \\
\hline I $8: 3$ & $1 \cdot 3$ & 0.07 & $I \cdot I$ & 0.5 & - & - \\
\hline $18: 4$ & 2.9 & 0.1 & 2.6 & 0.6 & - & - \\
\hline 20:I & $9 \cdot 8$ & 0.4 & $9 \cdot 9$ & II $\cdot 8$ & $\mathrm{I} 2 \cdot \mathrm{I}$ & $12 \cdot 6$ \\
\hline $20: 5$ & $7 \cdot 9$ & 0.2 & 6.6 & - & - & - \\
\hline $22: 1$ & $16 \cdot 3$ & 0.3 & 18.0 & $20 \cdot 1$ & 20.5 & $20 \cdot 8$ \\
\hline $22: 5$ & 0.7 & 0.2 & 0.3 & - & - & - \\
\hline $22: 6$ & $10 \cdot 1$ & 0.6 & 8.9 & 1.9 & - & - \\
\hline aturated & \multicolumn{2}{|c|}{$\begin{array}{r}23.5 \\
55.6\end{array}$} & 24.8 & $3 I \cdot 8$ & $35 \cdot 9$ & $34 \cdot 3$ \\
\hline Ionoene & \multicolumn{2}{|c|}{$51 \cdot 6$} & 54.8 & 63.8 & $6: 7$ & $65 \cdot 6$ \\
\hline iene & \multicolumn{2}{|c|}{$1 \cdot 9$} & I.9 & $\mathrm{I} \cdot 8$ & 0.5 & - \\
\hline $\begin{array}{l}\text { rl, tetra, } \\
\text { enta and } \\
\text { exaene }\end{array}$ & \multicolumn{2}{|c|}{$22 \cdot 9$} & 19.5 & $3 \cdot 0$ & - & - \\
\hline
\end{tabular}

* Herring oil ( $100 \mathrm{~g}$ ) and starch ( $300 \mathrm{~g}$ ) were mixed and irradiated with $400 \mathrm{krad}$ and, after $3 \mathrm{~d}$, added to the remainder of the untreated dietary components (for details, see p. 466). 


\section{Table 3. The effect of dietary lipid on the oxidative demethylation of aminopyrine}

(Mean values with their standard errors; no. of rats/experiment in parenthesis)

\begin{tabular}{|c|c|c|c|c|c|c|}
\hline \multirow[b]{3}{*}{$\operatorname{Diet}^{*}$} & \multicolumn{5}{|c|}{$\begin{array}{l}\text { Rate of aminopyrine demethylation } \\
\text { (nmol formaldehyde/min per mg protein) }\end{array}$} & \\
\hline & \multicolumn{2}{|c|}{ Basic } & & \multicolumn{2}{|c|}{ Induced $\ddagger$} & \\
\hline & Mean & SE & & Mean & SE & \\
\hline Coconut oil & $3 \cdot 26$ & 0.92 & $(8)$ & $7 \cdot 97$ & $I \cdot 10$ & (8) \\
\hline Lard & $3 \cdot 15$ & 0.84 & (9) & II $\cdot 22$ & 0.80 & (9) \\
\hline Maize oil & $5^{\circ} 03$ & 0.96 & (6) & 15.99 & $I \cdot 70$ & (6) \\
\hline \multicolumn{7}{|l|}{ Herring oil: } \\
\hline Non-irradiated & $6 \cdot 53$ & 0.66 & $(8)$ & $17 \cdot 60$ & $I \cdot 70$ & (8) \\
\hline Irradiated† & 4.83 & 0.57 & (8) & I 6.80 & 0.80 & $(8)$ \\
\hline
\end{tabular}

than in rats fed on a maize-oil diet. However feeding a diet containing herring oil irradiated with $400 \mathrm{krad}$ reduced the rate before induction $(P<0.00 \mathrm{I})$ as compared with the rate of demethylation in rats fed on an untreated herring-oil diet (Table 3).

\section{The effect of varying the fatty acid composition of the diet on the fatty acid composition of the liver endoplasmic reticulum}

The total amount of lipid extracted from the endoplasmic reticulum of rats fed on different diets did not vary whichever diet was fed. Phospholipids comprise $95 \%$ of the total endoplasmic reticulum membrane lipids (Victoria \& Barber, 1969) and thus any changes in proportions of a particular fatty acid in the liver endoplasmic reticulum will indicate altered incorporation of that fatty acid into the membrane phospholipids.

Changes in the endoplasmic reticulum fatty acid composition were observed after feeding the purified diets for only I-2 d but more constant compositions were attained after Io d feeding and the mean values shown in Table 4 are calculated from determinations on rats fed on the diets for at least $10 \mathrm{~d}$.

The proportions of palmitic (16:0) and stearic (18:0) acids in the endoplasmic reticulum of rats fed on diets containing different lipids did not vary widely (Table 4 ) although the quantity taken in was different depending on the diet fed (Table I). However, feeding a coconut-oil diet containing a high level of medium-chain saturated fatty acids caused incorporation of a substantial amount of lauric (I2:0) and myristic (14:0) acids into the endoplasmic reticulum as compared with feeding other diets (Table 4).

The proportions of unsaturated fatty acids in the endoplasmic reticulum of rats fed on different diets varied much more widely than those of saturated acids and reflected the unsaturated fatty acid compositions of the diets (Tables $\mathrm{I}$ and 4 ). Feeding a lard diet $\left(74 \mathrm{~g} \mathrm{C}_{18: 2} / \mathrm{kg}\right.$ ) or a coconut-oil diet ( $12 \mathrm{~g} \mathrm{C}_{18: 2} / \mathrm{kg}$ ) caused incorporation of smaller amounts of $\omega 6$ polyunsaturated fatty acids $\left(\mathrm{C}_{18: 2}\right.$ and arachidonic acid (20:4)) into the endoplasmic reticulum than after feeding the laboratory diet which contained $144 \mathrm{~g} \mathrm{C}_{18: 2} / \mathrm{kg}$ (Table 4 ). The liver endoplasmic reticulum of rats fed on a maize-oil diet, which contained $552 \mathrm{~g} \mathrm{C}_{18: 2} / \mathrm{kg}$, was composed of much higher proportions of both $\mathrm{C}_{18: 2}$ and $\mathrm{C}_{20: 4}$ than that of rats fed on 
Table 4. Fatty acid composition (\%) of liver microsomal lipid of rats fed on diets containing different lipids for 10-25d

(Mean values with their standard errors; no. of rats in parentheses)

\begin{tabular}{|c|c|c|c|c|c|c|c|c|c|c|}
\hline \multirow{2}{*}{$\begin{array}{c}\text { Diet }^{*} \ldots \\
\text { Fatty } \\
\text { acid }\end{array}$} & \multicolumn{2}{|c|}{$\begin{array}{l}\text { Laboratory } \\
\operatorname{diet} \dagger(6)\end{array}$} & \multicolumn{2}{|c|}{$\begin{array}{c}\text { Coconut } \\
\text { oil (I } 2)\end{array}$} & \multicolumn{2}{|c|}{ Lard (IO) } & \multicolumn{2}{|c|}{ Maize oil (IO) } & \multicolumn{2}{|c|}{$\begin{array}{l}\text { Herring } \\
\text { oil (1 } 2)\end{array}$} \\
\hline & Mean & SE & Mean & SE & Mean & SE & Mean & SE & Mean & SE \\
\hline I $2: 0$ & \multicolumn{2}{|c|}{ - } & $I \cdot I$ & 0.08 & \multirow{2}{*}{\multicolumn{2}{|c|}{-}} & \multicolumn{2}{|c|}{ - } & \multicolumn{2}{|c|}{-} \\
\hline $14: 0$ & \multicolumn{2}{|c|}{ 一 } & $4 \cdot 3$ & 0.2 & & & \multicolumn{2}{|c|}{-} & \multicolumn{2}{|c|}{ - } \\
\hline $16: 0$ & $26 \cdot I$ & 0.8 & $28 \cdot 5$ & 0.4 & $22 \cdot 8$ & $I \cdot I$ & $21 \cdot 2$ & 0.9 & $22 \cdot 3$ & 0.9 \\
\hline I6:1 & $4 \cdot 0$ & 0.3 & $9 \cdot 2$ & 0.4 & $4 \cdot 8$ & 0.8 & $2 \cdot 2$ & 0.2 & $3 \cdot 4$ & 0.1 \\
\hline I $8: 0$ & $16 \cdot 4$ & 0.6 & 14.5 & 0.4 & $17 \cdot 9$ & 0.9 & 15.9 & 0.9 & 16.0 & 0.5 \\
\hline $18: I$ & $2 \mathrm{I} \cdot \mathrm{I}$ & 0.6 & $23 \cdot 5$ & 0.3 & $26 \cdot 5$ & $1 \cdot 3$ & $15 \cdot 3$ & 0.9 & 17.8 & 0.5 \\
\hline I $8: 2$ & $14 \cdot 9$ & 0.4 & $7 \cdot 6$ & $0 \cdot 2$ & $10 \cdot 3$ & 0.6 & $25 \cdot 1$ & $1 \cdot 1$ & $5 \cdot 1$ & 0.3 \\
\hline $20: 1$ & \multicolumn{2}{|c|}{ - } & \multicolumn{2}{|c|}{ - } & \multicolumn{2}{|c|}{-} & \multicolumn{2}{|c|}{$\ldots$} & $1 \cdot 6$ & 0.2 \\
\hline $20: 4$ & I I 1 & 0.3 & $8 \cdot 8$ & 0.4 & 13.5 & 0.7 & $17 \cdot 8$ & 0.9 & $6 \cdot 4$ & 0.2 \\
\hline $20: 5$ & 0.7 & 0.1 & \multirow{2}{*}{\multicolumn{2}{|c|}{-}} & \multirow{2}{*}{\multicolumn{2}{|c|}{-}} & \multirow{2}{*}{\multicolumn{2}{|c|}{ 一 }} & $8 \cdot 7$ & 0.5 \\
\hline $22: 5$ & \multicolumn{2}{|c|}{ 一 } & & & & & & & $I \cdot 5$ & 0.3 \\
\hline $22: 6$ & $7 \cdot 7$ & 0.5 & $2 \cdot 6$ & 0.3 & $4 \cdot 3$ & 0.2 & $2 \cdot 5$ & 0.3 & $17 \cdot 0$ & 0.6 \\
\hline
\end{tabular}

* For details, see p. 466 .

$\dagger$ Spratts Laboratory Rat Diet no. I; Spratts Ltd, Barking, Essex.

other diets. Feeding a herring-oil diet, which supplied only $19 \mathrm{~g} \mathrm{C}_{18: 2} / \mathrm{kg}$, caused incorporation of relatively low amounts of $\mathrm{C}_{18: 2}$ and $\mathrm{C}_{20: 4}$ into the liver endoplasmic reticulum compared with feeding the laboratory diet (Table 4 ). However, a herring-oil diet provided large quantities of $\omega_{3}$ unsaturated fatty acids, including $\mathrm{C}_{20: 5}$ and $\mathrm{C}_{22: 6}$, and marked increases in the proportions of these two fatty acids in the liver endoplasmic reticulum were observed after only $2 \mathrm{~d}$ feeding. After 10-25 d feeding, there were $87 \mathrm{~g} \mathrm{C}_{20: 5}$ and $170 \mathrm{~g} \mathrm{C}_{22: 6} / \mathrm{kg}$ and, in addition, $15 \mathrm{~g} \mathrm{C}_{22: 5} / \mathrm{kg}$ in the liver endoplasmic reticulum (Table 4 ).

\section{The effect of irradiation of herring-oil on the fatty acid composition of the liver endoplasmic reticulum}

Irradiation of $100 \mathrm{~g}$ herring oil $+300 \mathrm{~g}$ starch with $400 \mathrm{krad}$ eventually caused complete destruction of all polyunsaturated fatty acids in the herring oil, the most-highly-unsaturated acids being destroyed most readily (Table 2). It is therefore possible to study the effect of feeding a herring-oil diet containing a lower proportion of highly-unsaturated fatty acids. Hammer $\&$ Wills (1979) have shown that most of the other components of herring oil, including the saturated and monounsaturated fatty acids, are relatively unaffected by this treatment. To examine the effect of irradiation, a I00 g herring oil + $300 \mathrm{~g}$ starch mixture was irradiated with $400 \mathrm{krad}$ and, after $3 \mathrm{~d}$, mixed with the rest of the untreated dietary components. After feeding the diet for $10-25 \mathrm{~d}$, the fatty acid composition of the liver endoplasmic reticulum was compared with that of rats fed on an unirradiated-herring-oil diet.

The proportions of $\mathrm{C}_{20: 5}$ and $\mathrm{C}_{22: 6}$, which were most readily destroyed by irradiation, were much lower in the endoplasmic reticulum of rats fed on the diet containing $100 \mathrm{~g}$ herring oil irradiated with $400 \mathrm{krad} / \mathrm{kg}$ than in that of rats fed on the unirradiated diet whereas the proportions of oleic ( $18: 1), \mathrm{C}_{18: 2}$ and $\mathrm{C}_{20: 4}$ acids in the liver endoplasmic reticulum were higher in rats fed on the irradiated-herring-oil diet (Table 5). 
Table 5. Fatty acid composition (\%) of liver microsomal lipid of rats fed on diets containing $100 \mathrm{~g}$ herring oil/ $\mathrm{kg}$ non-irradiated (control) or irradiated with $400 \mathrm{krad}^{*}$

(Mean values with their standard errors for 12 rats/group)

\begin{tabular}{|c|c|c|c|c|c|}
\hline \multirow[b]{2}{*}{ Fatty acid } & \multicolumn{2}{|c|}{ Control } & \multicolumn{2}{|c|}{ Irradiated } & \multirow{2}{*}{$\begin{array}{c}\text { Statistical signifi- } \\
\text { cance of difference } \\
\text { between } \\
\text { diets: } P\end{array}$} \\
\hline & Mean & SE & Mean & SE & \\
\hline $16: 0$ & $22 \cdot 3$ & 0.9 & $24 \cdot 3$ & 0.7 & - \\
\hline $16: 1$ & $3 \cdot 4$ & 0.1 & 5.7 & 0.5 & $<0.001$ \\
\hline $18: 0$ & 16.0 & 0.5 & 13.8 & 0.7 & $<0.002$ \\
\hline $18: 1$ & 17.8 & 0.5 & $27 \cdot 5$ & $I \cdot 2$ & $<0.001$ \\
\hline $18: 2$ & $5 \cdot I$ & 0.3 & $7 \cdot 5$ & 0.5 & $<0.001$ \\
\hline $20: 1$ & $1 \cdot 6$ & 0.2 & $2 \cdot 6$ & 0.3 & - \\
\hline $20: 4$ & $6 \cdot 4$ & 0.2 & $9 \cdot 5$ & 0.4 & $<0.001$ \\
\hline $20: 5$ & $8 \cdot 7$ & 0.5 & 0.6 & 0.3 & $<0.001$ \\
\hline $22: 5$ & $1 \cdot 5$ & 0.3 & & & - \\
\hline $22: 6$ & 17.0 & 0.6 & $8 \cdot 4$ & 0.5 & $<0.001$ \\
\hline
\end{tabular}

* Herring oil ( $100 \mathrm{~g}$ ) and starch ( $300 \mathrm{~g}$ ) irradiated with $400 \mathrm{krad}$ and, after $3 \mathrm{~d}$, added to the remainder of the untreated dietary components, see p. 466 for details.

The effect of phenobarbitone on the fatty acid composition of the liver endoplasmic reticulum after feeding diets containing different lipids

It is well established that drugs such as phenobarbitone cause induction of the enzymes involved in oxidative drug metabolism in the liver and extensive proliferation of the smooth endoplasmic reticulum membranes (Fouts \& Rogers, 1965; Remmer \& Merker, 1965). In view of the dependence of oxidative metabolism on membrane phospholipids, it was important to examine the effect of phenobarbitone on the fatty acid composition of the endoplasmic reticulum after feeding diets containing lipids of different fatty acid composition.

Phenobarbitone ( $100 \mathrm{mg} / \mathrm{kg}$ ) had little, if any, effect on the proportions of saturated fatty acids in the liver endoplasmic reticulum. The proportions of $\mathrm{C}_{18: 1}, \mathrm{C}_{18: 2}, \mathrm{C}_{20: 4}, \mathrm{C}_{20: 5}$ when present and $\mathrm{C}_{22: 6}$ acids in the liver endoplasmic reticulum were most readily altered by phenobarbitone. The changes shown in Fig. I are expressed as the difference in the contribution to the total fatty acids of $\mathrm{C}_{18: 1}, \mathrm{C}_{18: 2}, \mathrm{C}_{20: 4}, \mathrm{C}_{20: 5}$ or $\mathrm{C}_{22: 6}$ before and after phenobarbitone treatment.

Phenobarbitone significantly increased the proportion of $C_{18: 1}$ in the liver endoplasmic reticulum of rats fed on the lard $(P<0.02)$, maize-oil $(P<0.02)$, herring-oil $(P<0.05)$ and irradiated-herring-oil diets $(P<0.05)$. The proportion of $\mathrm{C}_{18: 2}$ in the liver endoplasmic reticulum of rats fed on the maize-oil diet was increased by phenobarbitone $(P<0.02)$ but was unchanged in rats fed on the lard or herring-oil diets and was decreased in rats fed on the irradiated-herring-oil diet $(P<0.05)$. The proportions of $\mathrm{C}_{20: 4}$ and $\mathrm{C}_{22: 6}$ in the liver endoplasmic reticulum were significantly decreased $(P=0.0 \mathrm{I}-0.05)$ by phenobarbitone treatment of rats fed on the lard, maize-oil, herring-oil and irradiated herring-oil diets (Fig. I). The proportion of $\mathrm{C}_{20: 5}$ in the liver endoplasmic reticulum of rats fed on the herringoil diet was increased $(P<0.05)$ by phenobarbitone (Fig. 1).

\section{The effect of $\alpha$-tocopherol on the fatty acid composition of the liver endoplasmic reticulum}

It has been suggested that $\alpha$-tocopherol maintains the integrity of the liver endoplasmic reticulum membranes by virtue of its antioxidant properties (Tappel, 1962) but Lucy (1972) has suggested that $\alpha$-tocopherol may be involved in the actual membrane structure, 

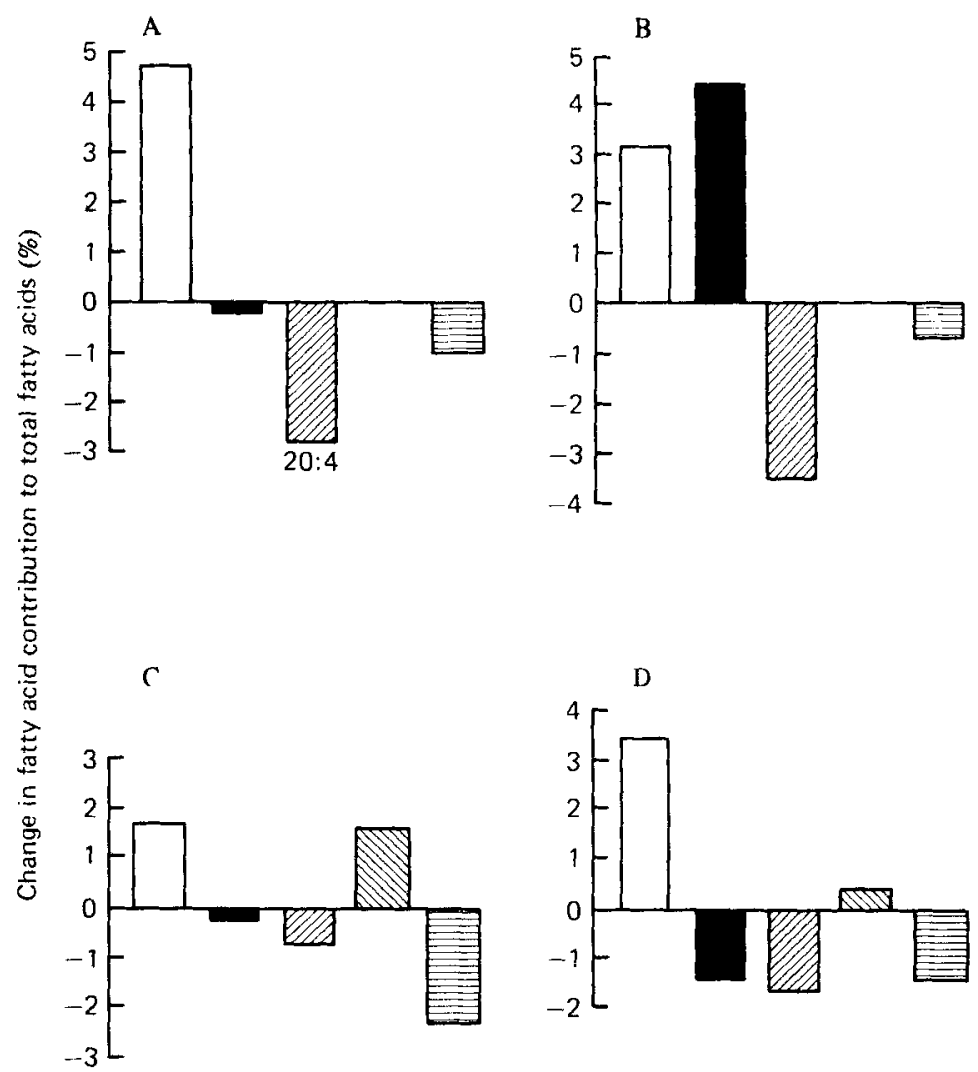

Fig. 1. The effect of phenobarbitone on the proportions of some unsaturated fatty acids in the liver endoplasmic reticulum of groups of twenty to twenty-four rats fed for $10-25 \mathrm{~d}$ on diets containing $100 \mathrm{~g} / \mathrm{kg}$ of the following lipids: lard (A), maize oil (B) or herring oil, untreated (C) or irradiated with $400 \mathrm{krad} 3 \mathrm{~d}$ before addition to the rest of the untreated diet (D). Ten to twelve rats in each group received a single injection of phenobarbitone $(100 \mathrm{mg} / \mathrm{kg})$ after at least $10 \mathrm{~d}$ on the diets and were killed $24 \mathrm{~h}$ later. Results are expressed as the difference in the contribution to the total fatty acids in the endoplasmic reticulum of oleic $(\square)$, linoleic ( $\square$ ), arachidonic $(\square)$, eicosapentaenoic ( $)$ or docosahexaenoic $(E)$ acid before and after phenobarbitone injection.

interacting with $\mathrm{C}_{20: 4}$ residues of membrane phospholipids. If $\alpha$-tocopherol is important in the membrane structure then it is possible that it could regulate the incorporation of polyunsaturated fatty acids into the liver endoplasmic reticulum.

Administration of $\alpha$-tocopherol twice weekly $(50 \mathrm{mg} / \mathrm{kg}$ ) during $15 \mathrm{~d}$ feeding caused increased incorporation of $\mathrm{C}_{20: 4}$ into the liver endoplasmic reticulum of rats fed on the lard and herring-oil diets $(P<0.05)$ but the proportions of other fatty acids were not significantly altered by $\alpha$-tocopherol (Table 6).

\section{DISCUSSION}

It is clear from the experiments described in this paper that the fatty acid composition of the dietary lipid has a marked influence on the fatty acid composition and the rate of oxidative demethylation in the liver endoplasmic reticulum.

When a highly-saturated coconut-oil diet was fed, the rate of oxidative demethylation 
Table 6. Fatty acid composition (\%) of liver microsomal lipid of rats fed on diets containing lard or herring oil for $15 d$ with or without twice weekly injections of $\alpha$-tocopherol $(\alpha-T ; 50 \mathrm{mg} / \mathrm{kg})$

(Mean values with their standard errors for ten rats in the control groups and four rats in the groups receiving $\alpha$-T injections)

\begin{tabular}{|c|c|c|c|c|c|c|c|c|}
\hline \multirow{3}{*}{$\begin{array}{l}\text { Fatty acid } \\
\qquad 16: 0\end{array}$} & \multicolumn{4}{|c|}{ Lard diet } & \multicolumn{4}{|c|}{ Herring oil diet } \\
\hline & \multicolumn{2}{|c|}{ Control } & \multicolumn{2}{|c|}{$+\alpha-T$} & \multicolumn{2}{|c|}{ Control } & \multicolumn{2}{|c|}{$+\alpha-T$} \\
\hline & $27 \cdot 5$ & $I \cdot O$ & $27 \cdot 2$ & 0.2 & 25.9 & 0.7 & $23 \cdot 6$ & 0.5 \\
\hline I6:I & $6 \cdot 0$ & 0.4 & 5.0 & 0.4 & $5 \cdot 5$ & 0.2 & $4 \cdot 5$ & 0.5 \\
\hline $18: 0$ & $15 \cdot 8$ & 0.5 & $16 \cdot 1$ & 0.5 & 15.0 & 0.7 & 16.0 & 0.3 \\
\hline $18: 1$ & $27 \cdot 3$ & 0.6 & $26 \cdot 8$ & 1.0 & $19 \cdot 2$ & 0.5 & $17 \cdot 8$ & 0.6 \\
\hline $18: 2$ & $9 \cdot \mathrm{I}$ & 0.2 & 9.0 & 0.2 & $5 \cdot 0$ & 0.3 & $6 \cdot 1$ & 0.6 \\
\hline $20: I$ & & & & & $1 \cdot 5$ & 0.1 & 1.9 & 0.4 \\
\hline $20: 4$ & $I I \cdot I$ & 0.5 & I $3 \cdot 1$ & $0.7^{*}$ & $5 \cdot 9$ & 0.3 & $7 \cdot 3$ & $0.4^{*}$ \\
\hline $20: 5$ & & & & & $7 \cdot 2$ & 0.4 & $7 \cdot 5$ & 0.3 \\
\hline $22: 5$ & & & & & $1 \cdot 1$ & 0.2 & 1.9 & 0.2 \\
\hline $22: 6$ & 2.9 & 0.2 & $3 \cdot 1$ & 0.1 & 13.7 & 0.5 & 13.5 & 0.8 \\
\hline
\end{tabular}

$* \boldsymbol{P}<0.05$ compared with control groups.

in the liver endoplasmic reticulum was less than when a maize-oil diet, which supplied a large proportion of polyunsaturated fatty acids $\left(55^{2} \mathrm{~g} \mathrm{C}_{18: 2} / \mathrm{kg}\right)$, was fed. The incorporation of $\omega 6$ polyunsaturated fatty acids $\left(C_{18: 2}\right.$ and $\left.C_{20: 4}\right)$ into the endoplasmic reticulum phospholipids was much lower in rats fed on the coconut-oil diet than in rats fed on the maize-oil diet but medium-chain saturated fatty acids were more readily incorporated and replaced the polyunsaturated acids (Table 4 ).

The high rate of oxidative demethylation observed after feeding the maize-oil diet was almost certainly due to the large proportion of $\omega 6 \mathrm{C}_{18: 2}$ and $\mathrm{C}_{20: 4}$ : acids incorporated into the liver endoplasmic reticulum (Table 4 ). A herring-oil diet, which supplied little $\mathrm{C}_{18: 2}$ but large quantities of $\omega 3$ polyunsaturated fatty acids including $\mathrm{C}_{20: 5}$ and $\mathrm{C}_{22: 6}$ acids (Table 1), also caused a high rate of oxidative demethylation (Table 3 ). This may be due to the presence of certain unsaponifiable components, such as cholesterol, in the herring oil, which become incorporated into the endoplasmic reticulum membrane. In support of this hypothesis, Lambert \& Wills (1977 $a$ ) demonstrated that the addition of the unsaponifiable matter of herring oil to lard diets caused a significant increase in the cytochrome $P_{450}$ content of the endoplasmic reticulum and of the rate of oxidative demethylation of aminopyrine. Incorporation of relatively large amounts of $\omega_{3}$ acids into the endoplasmic reticulum, which occurs after feeding a herring-oil diet (Table 4), could also be important because irradiation of the herring-oil diet caused a reduction in the proportion of $C_{20: 5}$ and $C_{22: 6}$ fatty acids incorporated into the membrane (Table 5) and also reduced the rate of oxidative demethylation of aminopyrine (Table 3). The effect of irradiation on all the unsaponifiable components of herring oil has not been established but sterols such as cholesterol are relatively resistant to irradiation and are unlikely to be affected by the dose of irradiation used. Increased incorporation of $\omega 6$ polyunsaturated fatty acids into the liver endoplasmic reticulum phospholipids was accompanied by decreased incorporation of $\omega_{3}$ acids and vice versa (Table 4 ) suggesting that the functions performed in the membrane by phospholipids containing $\omega 6$ acids can also be fulfilled by those containing $\omega_{3}$ acids if the former are not available.

Phenobarbitone injection ( $100 \mathrm{mg} / \mathrm{kg}$ ) increased the incorporation of $\mathrm{C}_{18: 2}$ into the endoplasmic reticulum of rats fed on the maize-oil diet and increased the incorporation 
of $C_{20: 5} \omega 3$ in rats fed on the herring-oil diet (Fig. I). This suggests that $C_{18: 2} \omega 6$ and $C_{20: 5}$ $\omega_{3}$ may be interchangeable in the membrane and either may be responsible for the increased rate of oxidative demethylation after phenobarbitone treatment of rats fed on the maizeoil or herring-oil diet (Table 3 ).

In addition to providing large amounts of $\mathrm{C}_{18: 2}$, the maize-oil diet also supplied I $\mathrm{mg}$ $\alpha$-tocopherol/g maize oil (Rowe \& Wills, 1976) which may be partly responsible for the increased rate of oxidative demethylation. $\alpha$-Tocopherol injection $(50 \mathrm{mg} / \mathrm{kg})$ caused increased incorporation of $\mathrm{C}_{20: 4}$ into the liver endoplasmic reticulum of rats fed on the lard and herring-oil diets which suggests that $\alpha$-tocopherol may have a specific structural role, possibly interacting with $\mathrm{C}_{20: 4}$ residues of membrane phospholipids as suggested by Lucy (1972).

The dietary lipid therefore alters the rate of oxidative demethylation in the liver endoplasmic reticulum by modification of the fatty acid composition of the membrane phopholipids and the composition of the diet must be taken into account when a fatty acid analysis of the endoplasmic reticulum is performed. In addition, the period of time of feeding the special diet must be considered. In the present investigation, rats were fed on the diets for up to 4 weeks but it is possible that further changes in fatty acid composition might occur after prolonged periods of feeding.

The supply of fatty acids in the diet may alter the rates of synthesis and degradation of the membrane phospholipids of the liver endoplasmic reticulum, so that when the dietary lipid comprises a large proportion of saturated fatty acids, there may be little synthesis de novo of membrane phospholipids because poiyunsaturated fatty acids are lacking, or the phospholipids may be synthesized containing a higher than normal proportion of saturated fatty acids. This could alter the molecular configuration of the membrane leading to decreased support for the bound enzyme system or a decreased affinity for binding substrates which may explain the low rate of oxidative demethylation in rats fed on a highly-saturated diet.

Davison \& Wills (1974) suggested that a species of phosphatidylcholine or phosphatidylethanolamine containing $C_{18: 2}$ in the $\beta$-position is essential in the membrane for maximum oxidative demethylation activity in the endoplasmic reticulum. Results of this present investigation suggest that if dietary $C_{18: 2}$ is in plentiful supply, as when feeding a maize-oil diet, $C_{18: 2}$ is preferentially incorporated, but if it is in short supply and there is a relatively high concentration of $\omega_{3}$ unsaturated acids, particularly $\mathrm{C}_{20: 5}$, in the diet then the latter may be able to replace $C_{18: 2}$ in the membrane and thus enhance the rate of oxidative demethylation. $C_{18: 2}$ $\omega 6$ or $\mathrm{C}_{20: 5} \omega_{3}$ in the liver endoplasmic reticulum as components of phopholipids thus appear to be important in holding the cytochrome $P_{450}$ enzyme complex in an active conformation in the membrane.

These experiments have demonstrated the ability of the dietary lipid to regulate oxidative demethylation in the liver and the importance of the fatty acid composition of the membrane phospholipids. A complete understanding of the role of the dietary lipid requires further studies of the dependence of oxidative demethylation on cytochrome $P 450$ and of the regulation of the activity of this haemoprotein by the phospholipids of the endoplasmic reticulum.

The authors wish to express their thanks to the International Project in the Field of Food Irradiation for a grant which supported the investigation, to Messrs Unigate for a supply of casein and antioxidant-free lard, to the Marfleet Refining Co. for a supply of herring oil, to the Tropical Products Institute for a supply of coconut oil, to Roche Ltd for a supply of retinol and cholecalciferol and to Bovril Ltd for a supply of dried yeast used for preparation of the diet. 


\section{REFERENCES}

Chapman, D. (1973). In Form and Function of Phospholipids p. 117, (G. B. Ansell, J. N. Hawthorne and R. M. C. Dawson, editors). Amsterdam: Elsevier.

Davison, S. C. \& Wills, E. D. (1974). Biochem. J. 142, 19.

Diplock, A. T., Bunyan, J., Green, J. \& Edwin, E. E. (I96I). Biochem. J. 79, 105.

Fouts, J. R. \& Rogers, L. A. (I965). J. Pharmac, exp. Ther. 147, I1 2.

Fricke, H., Hart, E. J. \& Smith, H. P. (1938). J. chem Phys. 6, 229.

Hammer, C. T. \& Wills, E. D. (1979). Int. J. Rad. Biol. (In the Press.)

Ingelman-Sundberg, M. (1977). Biochim. biophys. Acta 488, 225.

Ingelman-Sundberg, M. \& Gustafsson, J. (1975). Biochem. Soc. Trans. 3, 977.

Kamath, S. A. \& Rubin, E. (1972). Biochem. biophys. Res. Commun. 49, 52.

Lambert, L. \& Wills, E. D. (1977a). Biochem. Pharmac. 26, I417.

Lambert, L. \& Wills, E. D. (1977 b). Biochem. Pharmac. 26, I423.

Lu, A. Y. H., Junk, K. W. \& Coon, M. J. (1969). J. biol. Chem. 244, 3714.

Lucy, J. A. (1972). Ann. N. Y. Acad. Sci. 203, 4.

May, H. E. \& McCay, P. B. (1968), J. biol. Chem. 243, 2288.

Morrison, W. R. \& Smith, L. M. (1964). J. Lipid Res. 5, 600.

Recknagel, R. O.\& Ghoshal, A. K. (1966). In Biochemical Pathology p. 132, (E. Farber and P. N. Magee, editors). Baltimore: Williams \& Wilkins.

Remmer, H. \& Merker, H. J. (1965). Ann N. Y. Acad. Sci. 123, 79.

Rowe, L. \& Wills E. D. (1976). Biochem. Pharmac. 25, I75.

Strobel, H. W., Lu, A. Y. H., Heidema, J. \& Coon, M. J. (1970). J. Biol. Chem. 245, 485I.

Tappel, A. L. (1962). Vitam. Horm. 20, 493.

Victoria, E. J. \& Barber, A. A. (1969). Lipids 4, 582.

Wills, E. D. (I97I). Biochem. J. r23, 983. 